Mehmet Akif Ersoy Üniversitesi Fen Bilimleri Enstitüsü Dergisi 11(2): 130-141 (2020)

The Journal of Graduate School of Natural and Applied Sciences of Mehmet Akif Ersoy University 11(2): 130-141 (2020)

Araştırma Makalesi / Research Paper

\title{
Üniversite Öğrencilerinin Çevre Konularında Farkındalık, Bilinç ve Duyarılıık Seviyesinin Belirlenmesine Yönelik Bir Çalışma: Amasya Üniversitesi Kentsel Tasarım ve Peyzaj Mimarlığı Bölümü Örneği
}

\author{
Sultan Sevinç KURT KONAKOĞLU(D)1 \\ ${ }^{1}$ Amasya Üniversitesi, Mimarlık Fakültesi, Amasya \\ Geliş Tarihi (Received): 11.04.2020, Kabul Tarihi (Accepted): 19.05.2020 \\ $\square$ Sorumlu Yazar (Corresponding author): sultansevinckurt@gmail.com \\ (C) +903582500017 且 +903582500047
}

\section{ÖZ}

Dünyada sanayi devrimi sonrasında teknolojinin gelişmesine bağlı olarak hızlı kentleşme hareketleri, nüfus artışı, insanların doğayı bilinçsiz kullanımı ve doğaya hâkim olma düşüncesi görülmüştür. Yaşanan bu olayların sonucunda, doğal peyzaj dokusu bozularak doğa ile uyumlu olmayan kültürel peyzajlar ortaya çıkmış ve çevre sorunları insan yaşamını tehdit edecek önemli boyutlara ulaşmıştır. İnsanların çevreye bakış açılarını değiştirmeleri için üniversite öğrencilerinin çevre eğitimi alıp bilinçlenmeleri daha güvenli bir gelecek sağlamak adına önemlidir. Bu çalışmada, Amasya Üniversitesi Mimarlık Fakültesi Kentsel Tasarım ve Peyzaj Mimarlığı Bölümü lisans programında eğitim gören öğrencilerin çevre ile ilgili konularda farkındalık, bilinç ve duyarlıık seviyelerinin belirlenmesi amaçlanmıştır. Bu amaç doğrultusunda birinci sınıf, ikinci sınıf, üçüncü sınıf ve dördüncü sınıf öğrencilerinden olmak üzere toplam 112 öğrenci ile yüz yüze anket çalışması gerçekleştirilmiştir. Anket sorularına verilen cevapların frekans (yüzde) değerleri ve sorular arasındaki ilişkiler Ki-Kare testi ile SPSS 16.0 programı kullanılarak analiz edilmiştir Elde edilen bulgulara dayanılarak, öğrencilerin \%84,3'ünün çevre ile ilgili konularda farkında, bilinçli ve duyarlı olduğu, \%15,7'sinin ise farkında, bilinçli ve duyarlı olmadığı tespit edilmiştir. Öğrencilerin üniversitede almış oldukları çevre içerikli dersler, öğrencilerin okudukları sınıf ile çevreye karşı olan farkındalık, bilinç ve duyarlılık seviyeleri arasında istatistiksel olarak anlamlı bir ilişki olduğunu göstermektedir. Öğrencilerin okudukları sınıf haricinde demografik ve sosyo-ekonomik özelliklerine bağlı olmaksızın çevre sorunlarının farkında olduğu ve gündelik yaşamlarındaki tutum ve davranış biçimleri ile çevreye duyarlı olduğu görülmektedir.

Anahtar Kelimeler: Amasya, çevre bilinci, çevre duyarlıığı, çevre eğitimi, çevre farkındalığı

\section{A Study for Determining the Level of Consciousness, Awareness and Sensitivity of University Students on Environmental Issues: The Case Study of the Department of Urban Design and Landscape Architecture at the Amasya University, Turkey}

\begin{abstract}
Due to the development of technology after the industrial revolution in the world, rapid urbanization movements, population growth, people's unconscious use of nature and the idea of dominating nature have been observed. As a result of these events, the natural landscape texture has deteriorated and cultural landscapes that are incompatible with nature have emerged, and environmental problems have reached important dimensions that threaten human life. In order for university students to change their perspective on the environment, their environmental education and awareness should be provided to provide a safer future. This study aims to determine the environmental awareness,
\end{abstract}


environmental education and awareness levels of students studying in Amasya University Faculty of Architecture Urban Design and Landscape Architecture undergraduate program. For this purpose, a survey was applied to 112 students face to face, including first grade, second grade, third grade and fourth grade students. The frequency (percent) values of the answers given to the survey questions and the relationship between the questions were analyzed with the Chi-Square test using the SPSS 16.0 program. Research findings show that $84.3 \%$ of the students are aware, conscious and sensitive about environmental issues, and $15.7 \%$ are not aware, conscious and sensitive. It shows that there is a statistically significant relationship between environmental courses taken by students, students' classroom and the levels of awareness, consciousness and sensitivity towards the environment. It is concluded that students are aware of environmental problems and are sensitive to the environment with their attitudes and behaviors in their daily lives, regardless of their demographic and socio-economic characteristics.

Keywords: Amasya, environmental consciousness, environmental sensitivity, environmental education, environmental awareness

\section{GíRiş}

İnsanlığın başlangıcından günümüze kadar insan-doğaçevre daima ilişki içerisindedir. Leiss (1984)'e göre, insanoğlunun 'doğaya egemen olma' düşüncesi çok eski bir geçmişe sahiptir. Ancak bu düşüncenin, çağdaş dünya görüşü üzerinde kalıcı bir etki yaratması 18. yüzyılda olmuştur (Ertürk, 2018). 18. yüzyılda İngiltere'de başlayan sanayi devrimi öncesinde enerji üretimi bitki, hayvan, insanların el emeği ve kas gücünden yararlanılarak sağlanmıştır. Sanayi devrimiyle birlikte canlı enerji kaynaklarının yerini büyük ölçüde makine ve motorlar alarak insanoğlunun ürettiği ve tükettiği enerji düzeyi de artmıştır. Sanayi devrimi sonrası sanayileşmenin etkisiyle nüfusun artması, hızlı kentleşme hareketleri, insan intiyaç ve taleplerinin çoğalması, bilinçsiz tüketime bağlı olarak çevre sorunlarında artış görülmektedir. Bu durum, insanı doğadan uzaklaştırıp doğaya karşı duyarlılığını ortadan kaldırarak çevre sorunlarının büyük boyutlara ulaşmasına yol açmıştır. Çevre sorunlarının insan yaşamını tehdit edecek boyuta ulaşması tüm dünya ülkelerinin gündemine gelmiş ve küresel ölçekte çözüm bulunması gereken en önemli gündem maddesi olmuştur.

Ülkemizde 1982 Anayasası'nın 56. Maddesinde 'Herkes sağlıklı ve dengeli bir çevrede yaşama hakkına sahiptir, çevreyi geliştirmek, çevre sağlığını korumak ve çevre kirlenmesini önlemek devletin ve vatandaşların ödevidir' şeklinde belirtilmiştir (Çevre Kanunu, 2020). 2872 sayılı Çevre Kanunu ile de çevrenin korunması ve geliştirilmesine yönelik devlete ve bireylere aktif olarak katılmaları gereken bir görev verilerek çevre hakkı birçok ülkede kabul edilen çağdaş bir yaklaşımla benimsenmiştir (Ertürk, 1996; Demirkaya, 2006).

Çevre kavramı günlük yaşamda herkes tarafından kullanılmakta olup farklı anlamlar yüklenerek değişik şekillerde tanımlanmıştır.

Çevre kelimesi Fransızca etrafında anlamına gelen 'environ' kelimesinden türeyerek İngilizce karşılığı 'environment' kelimesi olmuştur (Young, 2011). 2872 sayılı
Çevre Kanunu'nun 2. maddesine göre çevre, 'Canlıların yaşamları boyunca ilişkilerini sürdürdükleri ve karşılıklı olarak etkileşim içinde bulundukları biyolojik, fiziksel, sosyal, ekonomik ve kültürel ortamı' ifade etmektedir (Çevre Kanunu, 2020). Demir ve Çevirgen (2006) çevreyi doğal ve sosyal yaşam içerisinde yer alan insanların birbirleriyle olan iletişim süreçleri, ilişkiler ağı ve birbirlerinden etkilenmesi olarak tanımlamaktadır. Keleş ve ark.'na (2015) göre çevre; insan faaliyetleri ve canlı varlıklar üzerinde dolaylı ya da dolaysız bir etkide bulunarak fiziksel, kimyasal, biyolojik ve toplumsal etmenlerin toplamını oluşturan bir kavramdır. En geniş tanımıyla çevre, insanı kuşatan ve çevreleyen cansız her şeydir (UNDP, 1993). Çevre kavramı farklı kaynaklarda farklı şekillerde tanımlanmış olsa da tanımların ortak noktası çevrenin canlı ve cansız tüm varlıklarla karşılıklı etkileşimlerinin olmasıdır. İnsanların çevre konusunda doğru davranışlar kazanabilmesi için çevre bilincine sahip olması büyük önem taşımaktadır. Çevre sorunlarının temelinde eğitimsizlik, duyarsızlık ve çevre bilinci eksikliği yatmaktadır. Insanlara çevre bilincinin kazandırılmasıyla çevre sorunları da çözümlenmiş olacaktır.

Çevre bilinci hem çevre sorunlarını önlemek hem de çevreyi korumak için insanlarda olması gereken bir düşünce biçimidir. Çevre bilinci temelde çevrenin farkında olma ve ona uyumlu davranabilmeyi gerektirmektedir (Nazlıoğlu, 1991). Çevre bilinci bireyin toplumsal olarak doğal çevresini kazanması, çevre duyarlılığı edinmesi, çevre ile ilgili sorunların çözülmesinde haklarını savunması ve tepkisini göstermesi için girişimlerde bulunması, çevreyi yok etmeden kullanması gereğinin kavranması, bütün tüketim alışkanlıklarında tasarrufun ön planda tutulması anlamına gelmektedir (Kızılaslan ve Kızılaslan, 2005; Öztek, 2006). Çevre bilinci, çevre sorunları karşısında insan tutum ve davranışlarının da önemli bir göstergesi olup sağlıklı ve dengeli bir çevrede yaşamayı desteklemektedir (Çolakoğlu, 2010). Çevre bilincine sahip bireyler, çevreye zarar verilmemesi, çevreye yararlı davranışlar sergilenmesi ve çevre sorunlarının çözümü hususunda bilinçli tüketim ve çevreci üretim anlayışını benimsemiştir (Çifci ve Şakacı, 2015; Onur ve ark., 
2016). Bu anlayış, uygulamaya geçilip davranışa dönüştüğü zaman çevre bilincinin göstergesi olarak kabul edilmektedir. Çevre sorunlarını çözmenin en temel yolu, toplumdaki bütün bireylere ciddi bir şekilde çevre eğitiminin verilerek çevre bilincinin kazandırılmasıdır. Çevreye yönelik yaklaşımların olumlu olarak değişmesi insanların çevre bilincini artırmaktadır (Şafak ve Erkal, 1995; Bozkurt ve Cansüngü, 2002; Karataş, 2014).

Çevre eğitimi, mevcut ve olası çevre sorunlarının çözümü için bireysel ya da ortak hareket noktasında insanlara bilgi, beceri, deneyim kazandırmasını sağlayarak çevre bilincini geliştiren bir eğitim süreci olarak tanımlanmaktadır (Karataş, 2014). Çevre eğitiminde çevre ile ilgili konularda bilinçli, mevcut çevre sorunlarının çözümüne katkı sağlayacak ve yeni sorunların oluşumunu engelleyecek, insanların davranışlarını olumlu yönde etkileyerek yaşam boyu sürmesini sağlayacak bir yaklaşımdır (Başal, 2003; Deniş ve Genç, 2010). Çevre eğitimi, insanlara çevre bilincinin kazandırılmasında en önemli etken ve koşul olarak görülmektedir. Bu doğrultuda çevre ile ilgili derslerin eğitim kurumlarında okulöncesinden başlayarak ilköğretim ve ortaöğretim kurumlarında zorunlu ders olarak okutulması, yükseköğretim kurumlarında ise ders müfredatında çevre konularına yer verilmesi gerekmektedir (Demirkaya, 2006; Karataş, 2014).

Ulusal ve uluslararası literatürde yer alan üniversite öğrencilerine yönelik çevre eğitimi ve çevre bilinci ile ilgili yapılmış çalışmalar aşağıdaki şekilde özetlenmiştir:

McKeown-Ice (2000), ABD'deki Amerikan Öğretmen Eğitimi Kolejleri Birliği (AACTE) üyesi üniversitelerde öğretmen yetiştiren eğitim programlarının çevre eğitim durumunu değerlendirmiştir. Çalışmada, ABD'deki üniversitelerin çoğunda öğretmen adayı lisans öğrencilerine daha bilinçli olmaları için çevre eğitimi verildiği ve çevre eğitiminin uygulanmasının da ABD'deki üniversitelerde farklılık gösterdiği tespit edilmiştir.

Çabuk ve Karacaoğlu'nun (2003) Ankara Üniversitesi Ĕğitim Bilimleri Fakültesi öğrencileri üzerinde yapmış olduğu çalışmada, öğrencilerin yaş, cinsiyet, okuduğu program ve sınıf gibi demografik özelliklerinin çevre duyarlılığına katkı sağlayıp sağlamadığı ele alınmıştır. Çaıışmada öğrencilerin okudukları program ve kişilik özelliklerine göre çevre duyarlılıkları arasında fark olduğu belirlenmiştir.

Wong (2003) Çin'in başkenti Pekin'de üniversite öğrencileri üzerinde gerçekleştirdiği çalışmada, üniversite öğrencilerinin Çin'in çevre ve kalkınma sorunlarına ilişkin algılarını ortaya koymuştur. Çalışmanın sonucunda öğrencilerin hem Çin'deki hem de dünyadaki çevre sorunlarının farkında ve bilincinde olduğu, öğrencilerin çevreyi korumak için daha fazla sivil toplum kuruluşlarının kurulması gerektiğini belirttikleri tespit edilmiştir.

Morgil ve ark. (2004)'nın yapmış olduğu çalışmada, bilgisayar destekli eğitimin üniversite öğrencilerinin çevre konularında farkındalık ve bilinç seviyelerini etkileme derecesi araştırılmıştır. Çalışma kimya öğretmenliği bölümünde son döneminde okuyan öğrenciler üzerinde gerçekleştirilmiştir. Öğrencilere ön test uygulandıktan sonra 2 hafta boyunca yoğun bir şekilde bilgisayar destekli öğretim yöntemi uygulanmıştır. Bilgisayar destekli eğitimden sonra öğrencilerin çevre bilgisinin ve farkındalığının arttığı, ancak başarı düzeyini tanımlamada çevre bilincinin gücünün azaldığı sonucuna ulaşılmıştır.

Özdemir ve ark. (2004)'nın yapmış olduğu çalışmada, üniversite öğrencilerinin çevre sorunlarının farkında olup olmadığı ve bu konudaki tutumları tespit edilmiştir. ÇaIışma tıp fakültesi birinci ve ikinci dönemlerinde okuyan öğrenciler üzerinde gerçekleştirilmiştir. Öğrencilerin çevre sorunlarının neler olduğunu tam anlayamadıkları ve çevre bilinçlerinin yeterli olmadığı sonucuna varılmıştır.

Talay ve ark. (2004), Ankara Üniversitesi'nde eğitim gören lisans öğrencilerinin çevre sorunları hakkında bilgi ve farkındalığını, çevreye karşı tutumlarını belirlemeye yönelik yaptığı çalışmada, Ankara Üniversitesi sağlık bilimleri haricindeki lisans öğrencilerinin çevre sorunlarının farkında olduğunu belirlemiştir.

Ramirez (2006)'in yapmış olduğu çalışmada, Avustralya'da endüstriyel tasarım programının bulunduğu 12 üniversitenin müfredatında çevresel sürdürülebilirlik konuları içeriğine sahip olup olmadığı ve öğrencilerin üniversitede tasarım programında aldıkları derslerin çevre duyarlıı̆ıına katkı sağlayıp sağlamadığı araştırıımıştır. Çalışmanın sonucunda 12 üniversitenin müfredatında çevresel sürdürülebilirlik konuları içeriğinin yer aldığı ve öğrencilerin üniversitede tasarım programında aldıkları derslerden etkilenerek çevreye duyarlı tasarımlar yaptıkları tespit edilmiştir.

Özden (2008) Adıyaman Üniversitesi Eğitim Fakültesi öğretmen adayı lisans öğrencileri üzerinde yapmış olduğu çalışmada, öğretmen adayı lisans öğrencilerinin tutumları ile yaş, cinsiyet, okuduğu program ve sınıf gibi demografik özelliklerinin, aile gelir düzeyinin, ebeveynlerin eğitim düzeyi ve mesleği arasındaki ilişkinin öğrencilerin çevre farkındalığına katkı sağlayıp sağlamadığı ele alınmıştır. Çalışmada öğrencilerin aile gelir düzeyi ile ebeveynlerin eğitim düzeyi ve mesleği arasında ilişki olduğu, aile gelir düzeyi yüksek olan öğrencilerin çevre sorunlarının farkında olduğu belirlenmiştir. 
Ozil ve ark. (2008) Kanada, Romanya ve Türkiye'deki mühendislik ve ekonomi alanlarındaki üniversite öğrencilerinin yenilenebilir enerji ve çevre konularındaki farkındalık düzeylerini belirlemiştir. Çalışma Kanada'da Dalhusie Üniversitesi ile Ryerson Üniversitesi, Romanya'da Sibiu Üniversitesi ile Bucharest Polytechnic Üniversitesi, Türkiye'de Yıldız Teknik Üniversitesi'nde gerçekleştirilmiştir. Çalışmada üç ülkenin de yenilenebilir enerji ve çevre konularının farkında olduğu görülmüştür.

Segalàs ve ark. (2009), İsveç'te Chalmers Teknik Üniversitesi, Hollanda'da Delft Teknik Üniversitesi, İsveç'te Catalonia Teknik Üniversitesi lisans mezunu öğrencileri üzerinde gerçekleştirdiği çalışmada Avrupa Yükseöğretim Alanı (EHEA) tanımlayıcılarını kullanarak üniversitede sürdürülebilirlik kavramını daha önce duyup duymadığı ve sürdürülebilirlik yeterliklerinin uygun olup olmadığını ortaya koymuştur. Çalışmanın gerçekleştirildiği üç üniversitenin de lisans mezunu öğrencilerinin sürdürülebilirlik kavramını üniversitede duyduğu ve üniversitelerin sürdürülebilirlik yeterliliklerinin sınıflandırılmasında aralarında küçük farklılıklar olduğu sonucuna ulaşılmıştır.

Kılıç ve İnal (2010)'ın yapmış olduğu çalışmada, çevre bilincinin üniversitede çevre ile ilgili bir ders alıp almamaya bağlı olup olmadığı ortaya konulmuştur. Çalışma, Niğde Üniversitesi İktisadi ve İdari Bilimler Fakültesi Kamu Yönetim Bölümü'nde çevre eğitimi dersi alan ve Niğde Üniversitesi İktisadi ve İdari Bilimler Fakültesi İşletme Bölümü'nde çevre eğitimi dersi almayan öğrenciler üzerinde gerçekleştirilmiştir. Çevre bilincinin ve çevre yaklaşımının üniversitede okunan bölüm ile ilgili olarak değişiklik gösterdiği sonucuna ulaşılmıştır.

Yaylı ve Berk (2010), Gazi Üniversitesi Kamu Yönetimi Bölümü öğrencileri üzerinde bir çalışma gerçekleştirmiştir. Çalışmada, çevre sorunları dersini okuyan ve okumayan öğrencilerin çevre sorunlarına karşı duyarlılıkları ve davranışları ortaya konulmuştur. Dersi okuyan öğrencilerin dersi okumayan öğrencilere göre çevre sorunlarına karşı duyarlı olduğu görülmüştür.

Oğuz ve ark. (2010), Ankara ilinde farklı üniversitelerde eğitim gören peyzaj mimarlığı, çevre mühendisliği, şehir ve bölge planlama bölümü öğrencilerinin çevre sorunları ile ilgili farkındalık, tutum ve duyarlılık düzeylerini tespit etmek amacıyla bir çalışma gerçekleştirmiştir. Çalışmada, öğrencilerin çevre bilincinin düşük olduğu ve öğrencilerin seviyesi için yapılan programın yeniden gözden geçirilmesinin uygun görüldüğü sonucuna ulaşılmıştır.
Oğuz ve ark. (2011)'nın yapmış olduğu çalışmada, üniversite öğrencilerinin çevre bilinci ölçülmesi ele alınmıştır. Çalışma Ankara ilinde farklı üniversitelerde eğitim gören peyzaj mimarlığı, çevre mühendisliği, şehir ve bölge planlama bölümü birinci ve dördüncü sınıf öğrencileri üzerinde gerçekleştirilmiştir. Çalışmanın sonucunda dördüncü sınıf öğrencilerinin çevre kavramını tam olarak tanımlayamadıkları, birinci sınıf ile dördüncü sınıf öğrencileri arasında çevre bilinci açısından fark olduğu, üniversitede verilen derslerin yeterli olmadığı görülmüştür.

Aminrad ve ark. (2011) Malezya Üniversitesi öğrencilerinin yaş ve eğitim düzeyi (lisans, yüksek lisans ve doktora) faktörlerine göre çevre farkındalığını belirlemek üzere bir çalışma gerçekleştirmiştir. Çalışmanın sonucunda öğrencilerin yaş ve eğitim düzeyleri arasında anlamlı bir ilişki olduğu ve bu durumun çevre farkındalığına olumlu katkı sağladığı görülmüştür.

Aydın (2011), Karabük Üniversitesi'nde eğitim gören lisans öğrencilerinin çevre kavramı hakkında sahip oldukları algıları metaforlar aracılığıyla ortaya koymuştur. ÇaIışma kapsamında öğrenciler çevre kavramına ilişkin metafor üretmişlerdir. Çalışmanın sonucunda, üniversite öğrencilerinin çevre kavramına ilişkin sahip oldukları algıları anlamada ve açıklamada metaforların önemli bir araştırma aracı olduğu anlaşılmıştır.

Maffia ve ark. (2011), Minas Gerais Federal Üniversitesi'nde çevre bilimleri, matematik, biyoloji ile dil ve sanat bölümlerinde okuyan öğrencilerin çevre farkındalığını çizim tekniğini kullanarak analiz etmiştir. Çalışmanın sonucunda çevre bilimlerinde okuyan öğrencilerin matematik, biyoloji ile dil ve sanat bölümlerinde okuyan öğrencilere göre daha fazla sayıda çevre sorunu tespit ettiği, üniversitelerde çevre eğitimi içerikli derslerin sayısının arttırıması gerektiği görülmüştür.

Gürbüz ve Çakmak (2012), Dicle Üniversitesi Ziya Gökalp Eğitim Fakültesi Biyoloji Eğitimi Bölümü öğretmen adayı lisans öğrencileri üzerinde bir çalışma gerçekleştirmiştir. Çalışmada, öğrencilerin cinsiyetleri ile en uzun süre yaşadıkları yerleşim birimi açısından çevreye yönelik tutumları arasında anlamlı bir ilişki olmadığı, öğrencilerin okudukları sınıf ile çevreye yönelik tutumları arasında anlamlı bir ilişki olduğu ortaya konulmuştur.

Erdal ve ark. (2013)'nın yapmış olduğu çalışmada, Gaziosmanpaşa Üniversitesi öğrencilerinin çevre ile ilgili konularda bilinç seviyelerinin belirlenmesi ele alınmıştır. Çalışmaya katılan öğrencilerin çoğunluğunun çevre sorunlarının farkında ve çevre sorunlarına duyarlı olduğu, üniversitelerde çevre derslerinin zorunlu bir ders olarak okutulması gerektiğini savundukları tespit edilmiştir. 
Karataş (2014), çevre sorunlarının çözümünde yükseköğretimde verilen çevre eğitiminin önemini vurgulayan bir çalışma gerçekleştirmiştir. Çalışmada, daha güvenli bir gelecek için yükseköğretimde verilen çevre eğitiminin gençlerin çevre bilincine katkı sağlayacağı sonucuna varılmıştır.

Panth ve ark. (2015)'nın çalışmasında, 'Çevre, İnsan ve Toplum' dersi kapsamında lisans öğrencilerinin çevreye karşı tutumlarını cinsiyet ve okudukları fakülte faktörüne göre incelemiştir. Dersi alan bayan öğrencilerin erkek öğrencilere göre çevreye karşı daha duyarlı ve bilinçli olduğu sonucuna varılmıştır.

Özen ve Özen (2017), Fırat Üniversitesi Veteriner Fakültesi öğrencilerinin çevre konusundaki görüşlerini belirlemek amacıyla bir çalışma gerçekleştirmiştir. Çalışmada, öğrencilerin hem dünyada hem de Türkiye'de yaşanan çevre sorunlarının, veteriner halk sağlığının öneminin ve veteriner hekimliği uygulamalarına bağlı çevresel risklerin farkında olduğu belirlenmiştir.

Demirtaş ve ark. (2018) Ankara Üniversitesi Beypazarı Meslek Yüksekokulu öğrencilerinin çevre sorunlarına yönelik fikirlerini ve çevresel okuryazarlık düzeylerini belirlemek amacıyla çalışma gerçekleştirmişlerdir. Çalışmanın sonucunda öğrencilerin çevre okuryazarlılığı düzeylerinin cinsiyete, aldıkları çevre eğitimine, okudukları programlara ve yurtdışı deneyimine göre farklılık gösterdiği tespit edilmiştir.

Gül ve ark. (2018)'nın yapmış olduğu çalışmada, Ondokuz Mayıs Üniversitesi Fen Edebiyat Fakültesi, Eğitim Fakültesi ve Kavak Meslek Yüksekokulu öğrencilerinin cinsiyeti, öğrenim gördüğü programı, aldıkları çevre dersi sayısı ve hayatlarının büyük bir bölümünün geçtiği yerleşim biriminin çevre bilincini etkileyip etkilemediği incelenmiştir. Çalışmada; bayan öğrencilerin erkek öğrencilere göre çevre bilincinin yüksek olduğu, üniversite öğrencilerinin öğrenim gördükleri program ile hayatlarının büyük bir bölümünün geçtiği yerleşim biriminin çevre bilincine etkisinin olmadığı, yükseköğretimde verilen çevre içerikli derslerin niteliği ile ilgili çalışmalar yapılması gerektiği sonucuna varılmıştır.

Bu çalışmada; üniversitede lisans programında verilen çevre eğitimi içerikli derslerin öğrencilerin çevre ile ilgili konularda farkındalık, bilinç ve duyarlılık seviyelerine katkı sağlayıp sağlamadığını belirlemek amaçlanmıştır. Çalışma bu amaç doğrultusunda, Amasya Üniversitesi Mimarlık Fakültesi Kentsel Tasarım ve Peyzaj Mimarlığı Bölümü lisans öğrencileri üzerinde gerçekleştirilmiştir. Peyzaj mimarlığı; insan ile çevre arasındaki ilişkiyi irdeleyen, doğal ve kültürel kaynakları koruma-kullanma dengesi içerisinde tasarlanmasını, planlanmasını ve yö- netilmesini ele alan, sanatı, bilimi, mühendisliği ve teknolojiyi birleştiren bir meslek disiplini olup mimarlık, şehir ve bölge planlama, ekoloji, jeoloji, coğrafya, ormancılık, ziraat, güzel sanatlar, toprak, botanik, sosyoloji gibi meslek disiplinleri ile etkileşim içerisindedir. Peyzaj mimarlığı meslek disiplininde amaç, doğadan koparılmış sosyal, fiziksel ve psikolojik açıdan baskı altında olan kent insanına doğa ile ilişki kurabileceği yeşil bir çevre yaratmak olduğu için peyzaj mimarlarının çevre sorunlarının farkında olup buna göre tasarım ya da planlama çözüm önerisi sunması beklenmektedir.

\section{MATERYAL VE YÖNTEM}

$\mathrm{Bu}$ çalışmada 'üniversite öğrencilerinin lisans programında almış oldukları çevre eğitimi içerikli derslerin öğrencilerin çevre ile ilgili konularda farkındalık, bilinç ve duyarlılık seviyelerine katkı sağladığı yönünde' varsayımından yola çıkılmıştır. Çalışma, Amasya Üniversitesi Mimarlık Fakültesi Kentsel Tasarım ve Peyzaj Mimarlığı Bölümü'nde 2018-2019 Eğitim-Öğretim Yılı Bahar Yarıyılı ile 2019-2020 Eğitim-Öğretim Yılı Güz Yarıyılında ders yürütücüsü olarak çevre eğitimi içerikli vermiş olduğum 'Kentsel-Çevresel Konu ve Kavramlara Giriş', 'Çevresel-Okur Yazarlık', 'Ekoloji Odaklı Planlama ve Tasarım' dersleri kapsamında gerçekleştirilmiştir. Çalışmanın amacı, üniversitede lisans programında verilen çevre eğitimi içerikli derslerin öğrencilerin çevre ile ilgili konularda farkındalık, bilinç ve duyarlııı seviyelerine katkı sağlayıp sağlamadığını belirlemektir. Bu amaç doğrultusunda daha önce bu konuda yapılmış Çabuk ve Karacaoğlu (2003), Özdemir ve ark. (2004), Oğuz ve ark. (2010, 2011), Erdal ve ark. (2013), Demirtaş ve ark. (2018), Gül ve ark. (2018)'nın çalışmalarından yararlanılarak 15 sorudan oluşan bir anket hazırlanmıştır. Anket çalışması derslerimi alan birinci sınıf, ikinci sınıf, üçüncü sınıf ve dördüncü sınıf olmak üzere toplam 143 öğrenciden gönüllü olan 112 öğrenci üzerinde yürütülmüştür. Anket sorularına verilen cevapların frekans (yüzde) değerleri SPSS 16.0 istatistik programında değerlendirilmiştir. Demografik özellikler ile ilgili birçok ilişki test edilmiştir. Öğrencilerin üniversitede almış oldukları çevre içerikli dersler, okudukları sınıf ile çevre ile ilgili konularda farkındalık, bilinç ve duyarılık seviyeleri arasında ilişki olup olmadığı, öğrencilerin okudukları sınıf ile çevre kavramını doğru bir şekilde tanımlayıp tanımlayamadığı, öğrencilerin okudukları sınıf ile sürdürülebilirlik kelimesini daha önce duyup duymadığı Ki-Kare testi ile analiz edilmiştir. Bütün istatistik analizlerin $\% 95$ güven aralığında $0.5 \times 0.5$ varyansla, 0.1 'lik hata payıyla gerçekleştiği kabul edilmiştir. 


\section{BULGULAR}

112 öğrenci ile yüz yüze gerçekleştirilen anket çalışmasında, verilerin analizinde betimleyici istatistik yöntemleri kullanılarak verilere ait frekans (yüzde) değerleri tablolar halinde özetlenmiştir.
Çalışmaya katılan 112 öğrencinin \%17,9'u birinci sınıf, $\% 16,1$ 'i ikinci sınıf, \%50,9'u üçüncü sınıf, \%15,2'si ise dördüncü sınıftır. Öğrencilerin demografik ve sosyo-ekonomik özellikler açısından cinsiyet, yaş, yaşadığı yer ve ailesinin aylık gelir dağılımları Tablo 1'de verilmiştir.

Tablo 1. Öğrencilerin demografik ve sosyo-ekonomik özelliklerine göre dağılımları

\begin{tabular}{|c|c|c|c|}
\hline ÖZELLİK & & Kişi SAYISI & YÜZDE (\%) \\
\hline \multirow{2}{*}{ Cinsiyet } & Bayan & 55 & 49,1 \\
\hline & Erkek & 57 & 50,9 \\
\hline \multirow{4}{*}{ Yaş } & $18-20$ & 32 & 28,6 \\
\hline & $21-23$ & 64 & 57,1 \\
\hline & $24-26$ & 11 & 9,8 \\
\hline & 27 ve üstü & 5 & 4,5 \\
\hline \multirow{4}{*}{ Okuduğu sınıf } & 1. $\sin I f$ & 20 & 17,9 \\
\hline & 2.sınıf & 18 & 16,1 \\
\hline & 3.sınıf & 57 & 50,9 \\
\hline & 4.sınıf & 17 & 15,2 \\
\hline \multirow{4}{*}{ İkamet ettiği yer } & Köy & 9 & 8,0 \\
\hline & İlçe & 25 & 22,3 \\
\hline & Şehir & 29 & 25,9 \\
\hline & Büyükşehir & 49 & 43,8 \\
\hline \multirow{6}{*}{ Ailenin aylık geliri } & $0-500 \mathrm{TL}$ & 6 & 5,4 \\
\hline & $500-1000 \mathrm{TL}$ & 3 & 2,7 \\
\hline & $1000-1500 \mathrm{TL}$ & 13 & 11,6 \\
\hline & $1500-3000 \mathrm{TL}$ & 38 & 33,9 \\
\hline & $3000-5000 \mathrm{TL}$ & 36 & 14,3 \\
\hline & 5000 TL ve üstü & 16 & 14,3 \\
\hline
\end{tabular}

Tablo 1'de görüldüğü üzere çalışmaya katılan öğrencilerin \%50,9'u erkek, \%49,1'i bayandır. Öğrencilerin $\% 57,1$ 'nin 21-23 yaş aralığında olduğu, ikamet ettikleri yerin çoğunlukla \%43,8 ile büyükşehir olduğu tespit edilmiştir. Ailelerinin aylık gelir durumlarına bakıldığında \%33,9'u 1500-3000 TL aralığındadır.

Öğrencilere 'Çevre kavramı size ne ifade etmektedir?' şeklinde açık uçlu bir soru sorulmuş olup öğrencilerin $\% 83,0$ 'ü çevre kavramını doğru tanımlamış, \%17,1'i çevre kavramını doğru ve yeterli biçimde tanımlayamamıştır. Çevre kavramını, daha çok birinci sınıf öğrencilerinin doğru bir şekilde tanımlayamadığı görülmüştür.

Öğrencilere daha önce (ilköğretim ya da ortaöğretim) herhangi bir çevre eğitimi alıp almadığı sorulmuştur. Ankete katılanların \%32,1'i çevre eğitimi aldığı, $\% 67,9$ 'unun çevre eğitimi almadığı belirlenmiştir. 'Daha önce herhangi bir çevre etkinliğine katıldınız mı?' sorusuna katılanların \%58,9'u 'Evet', \%41,1'i 'Hayır' cevabını vermiştir. Derslerim kapsamında ikinci sınıf, üçüncü sınıf ve dördüncü sınıf öğrencileri ile fidan dikimi etkinliği yapıldığı için öğrencilerin \%58,9'u bu soruya 'Evet' cevabını vermişlerdir. 'Evet' cevabını veren öğrencilerin çoğu üniversite eğitimi süresince çevre etkinliğine katıldığını ilköğretim ya da ortaöğretimde çevre etkinliğine katılmadığını da belirtmiştir.

Öğrencilere Türkiye'de çevre konusunda faaliyet gösteren başlıca STK (Sivil Toplum Kuruluşları)'ları tanıyıp tanımadıkları sorulmuştur. Öğrencilerin \%43,8'inin STK'ları tanıdığı, \%56,2'sinin ise tanımadığı belirlenmiştir. TEMA, Çevre Koruma ve Ambalaj Atıkları Değerlendirme Vakfı (ÇEVKO), Türkiye Çevre Eğitimi Vakfı (TÜRÇEV), Greenpeace, AHBAP Derneğinin öğrenciler tarafından en çok bilinen STK'lar olduğu görülmüştür. 'Çevre faaliyeti yürüten üye olduğunuz bir STK, kuruluş ya da organizasyon var mı?' sorusuna katılanların \%7,1'i 'Evet', \%92,9'u 'Hayır' cevabını vermiştir. Bu soruya 
'Evet' cevabı veren 8 kişinin \%25’i AHBAP Derneğine, $\% 75$ 'i de TEMA Vakfına üye olduğunu belirtmiştir.

'Size göre Türkiye'de önemli çevre sorunları nelerdir?' diye sorulduğunda katılanların \%15,8'i ilk sırada 'Hava kirliliği', \%15,2'si ikinci sırada 'İklim değişikliği-küresel ısınma', \%12,2'si üçüncü sırada 'Su kirliliği', \%11,9'u dördüncü sırada 'Çarpık kentleşme', \%10,1'i beşinci sırada 'Doğal kaynakların azalması', \%8,0'i 'Gürültü kirliliği', \%7,7'si 'Görüntü kirliliği', \%7,4'ü 'Toprak kirliliği', $\% 5,4$ 'ü 'Atıklardan doğan kirlilik', \%3,9'ü 'Yangınlar', $\% 2,1$ 'i 'Baz istasyonları' ve \%0,3'ü 'Diğer' cevabını vermiştir (Tablo 2). Öğrencilerin verdikleri cevaplara göre, Türkiye'de görülen çevre sorunlarının farkında ve bilincinde olduğu görülmektedir.

Tablo 2. Öğrencilere göre Türkiye'de görülen önemli çevre sorunları dağılımı

\begin{tabular}{|l|c|c|}
\hline \multicolumn{1}{|c|}{ ÇEVRE SORUNLARI } & Kişi SAYISI & YÜZDE (\%) \\
\hline Hava kirliliği & 53 & 15,8 \\
\hline İklim değişikliği-küresel ısınma & 51 & 15,2 \\
\hline Su kirliliği & 41 & 12,2 \\
\hline Çarpık kentleşme & 40 & 11,9 \\
\hline Doğal kaynakların azalması & 34 & 10,1 \\
\hline Gürültü kirliliği & 27 & 8,0 \\
\hline Görüntü kirliliği & 26 & 7,7 \\
\hline Toprak kirliliği & 25 & 7,4 \\
\hline Atıklardan doğan kirlilik & 18 & 5,4 \\
\hline Yangınlar & 13 & 3,9 \\
\hline Baz istasyonları & 7 & 2,1 \\
\hline Diğer & 1 & 0,3 \\
\hline TOPLAM & $336^{*}$ & 100,0 \\
\hline
\end{tabular}

*Soru çoklu yanıt olduğu için kişi sayısı (N) örneklem hacmini geçmektedir.

Öğrencilerin \%79,5’inin sürdürülebilirlik kelimesini daha önce duyduğu, daha çok birinci sınıf öğrencilerinin yer aldığı \%20,5'inin de duymadığı görülmüştür. Öğrencilere 'Çevre duyarlıığı konusunda nasıl bir tutum sergilemektesiniz?' sorusu sorularak çevre duyarlılığı konusunda kendilerini ' 5 'li Likert Ölçeği'ne göre değerlendirmeleri istenmiştir (Tablo 3). 5'li Likert ölçeğinde kesinlikle katılıyorum (5), katılıyorum (4), fikrim yok (3), katılmıyorum (2), kesinlikle katılmıyorum (1) şeklinde tanımlanmıştır. Ölçek puanının yüksek olması öğrencinin çevre ile ilgili konularda farkındalık, bilinç ve duyarlılık seviyesinin yüksek olduğunu, puanın düşük olması ise öğrencinin çevre ile ilgili konularda farkındalık, bilinç ve duyarlılık seviyesinin düşük olduğunu göstermektedir.

Öğrencilere 'Çevre ve insan sağlığı açısından düşüncelerinizi size uygun olan seçeneği işaretleyiniz' sorusu sorularak kendilerini ' 5 'li Likert Ölçeği'ne göre değerlendirmeleri istenmiş ve sonuçları Tablo 4'te verilmiştir. 
Tablo 3. Öğrencilerin çevre duyarııı̆̆ konusundaki görüşleri dağııımı

\begin{tabular}{|l|c|c|c|c|c|}
\hline \multicolumn{1}{|c|}{ BİLiNÇ DÜZEYi } & $\mathbf{1}$ & $\mathbf{2}$ & $\mathbf{3}$ & $\mathbf{4}$ & $\mathbf{5}$ \\
\hline $\begin{array}{l}\text { Cam, plastik, kâğıt çöplerini ayrı ayrı atmaya özen } \\
\text { gösteririm }\end{array}$ & 2,7 & 6,2 & 6,2 & $\mathbf{6 2 , 5}$ & 22,3 \\
\hline $\begin{array}{l}\text { Alışverişlerimde bez torba/file kullanmayı tercih ede- } \\
\text { rim }\end{array}$ & 2,7 & 15,2 & 17,9 & $\mathbf{4 2 , 0}$ & $\mathbf{2 2 , 3}$ \\
\hline Elektrik/suyu gereksiz kullanmaktan kaçınırım & 3,6 & 2,7 & 3,6 & $\mathbf{3 4 , 8}$ & $\mathbf{5 5 , 4}$ \\
\hline $\begin{array}{l}\text { Ambalajında geri dönüşüm işareti olan ürünleri almaya } \\
\text { özen gösteririm }\end{array}$ & 4,5 & 24,1 & $\mathbf{3 5 , 7}$ & $\mathbf{2 6 , 8}$ & $\mathbf{8 , 9}$ \\
\hline $\begin{array}{l}\text { Fosil yakıt tüketimini azaltmak için toplu taşıma } \\
\text { aracı/bisiklet kullanmaya özen gösteririm }\end{array}$ & 8,9 & 15,2 & 19,6 & $\mathbf{3 4 , 8}$ & 21,4 \\
\hline Çevreyi kirletenleri gördüğümde uyarırım & 2,7 & 8,9 & 11,6 & $\mathbf{5 2 , 7}$ & 24,1 \\
\hline $\begin{array}{l}\text { Yenilenebilir enerji kaynaklarını kullanmayı tercih ede- } \\
\text { rim }\end{array}$ & 0,9 & 8,9 & 16,1 & $\mathbf{5 0 , 9}$ & $\mathbf{2 3 , 2}$ \\
\hline Çevre ile ilgili düzenlenen etkinliklere katıırım & 8,0 & 19,6 & 26,8 & $\mathbf{3 0 , 4}$ & 15,2 \\
\hline Organik gıdaları alıp tüketmeye çalışırım & 0,0 & 6,2 & 16,1 & $\mathbf{4 2 , 0}$ & 35,7 \\
\hline
\end{tabular}

1: Kesinlikle Katılmıyorum, 2: Katılmıyorum, 3: Fikrim Yok, 4: Katılıyorum, 5: Kesinlikle Katılıyorum

Tablo 4. Öğrencilerin çevre ve insan sağlığı açısından görüşleri dağılımı

\begin{tabular}{|l|c|c|c|c|c|}
\hline \multicolumn{1}{|c|}{ BíLiNÇ DÜZEYi } & $\mathbf{1}$ & $\mathbf{2}$ & $\mathbf{3}$ & $\mathbf{4}$ & $\mathbf{5}$ \\
\hline $\begin{array}{l}\text { Bilinçsizce kullanılan tarım ilaçları ekolojik dengeyi } \\
\text { olumsuz etkilemektedir }\end{array}$ & 1,8 & 0,9 & 1,8 & 29,5 & $\mathbf{6 6 , 1}$ \\
\hline $\begin{array}{l}\text { Doğal su kaynaklarının kirlenmesi biyolojik çeşitliliği } \\
\text { doğrudan olumsuz etkilemektedir }\end{array}$ & 1,8 & 0,0 & 0,9 & 21,4 & $\mathbf{7 5 , 9}$ \\
\hline $\begin{array}{l}\text { Atıkların arıtılarak akarsu ve denizlere ulaştırılması } \\
\text { gerekmektedir }\end{array}$ & 10,7 & 7,1 & 7,1 & 17,0 & $\mathbf{5 8 , 0}$ \\
\hline $\begin{array}{l}\text { Kentlerde yer alan yeşil alanlar insan sağlığı açısından } \\
\text { olumlu etkilere sahiptir }\end{array}$ & 1,8 & 1,8 & 0,9 & 13,4 & $\mathbf{8 2 , 1}$ \\
\hline $\begin{array}{l}\text { Fabrikaların/çöp alanlarının konut alanlarına yakın ol- } \\
\text { ması insan sağlığını ve yaşam kalitesini olumsuz etki- } \\
\text { lemektedir }\end{array}$ & 1,8 & 0,9 & 0,9 & 16,1 & $\mathbf{8 0 , 4}$ \\
\hline $\begin{array}{l}\text { Kentlerde gürültü kirliliği insan sağlığını olumsuz etki- } \\
\text { lemektedir }\end{array}$ & 0,9 & 0,0 & 3,6 & 35,7 & $\mathbf{5 9 , 8}$ \\
\hline $\begin{array}{l}\text { Yenilenebilir enerji kaynaklarının kullanımının yaygın- } \\
\text { laştırılması hava kirliliğinin azalmasını sağlamaktadır }\end{array}$ & 1,8 & 0,9 & 0,9 & 16,1 & $\mathbf{8 0 , 4}$ \\
\hline $\begin{array}{l}\text { Kentlerde görsel kirlilik (çarpık kentleşme, yeşil alan } \\
\text { yetersizliği) beni rahatsız etmektedir }\end{array}$ & 0,9 & 1,8 & 3,6 & 22,3 & $\mathbf{7 1 , 4}$ \\
\hline
\end{tabular}

1: Kesinlikle Katılmıyorum, 2: Katılmıyorum, 3: Fikrim Yok, 4: Katılıyorum, 5: Kesinlikle Katılıyorum 
Tablo 3 ile 4 irdelendiğinde; öğrencilerin \%84,3'ünün çevre ile ilgili konularda farkında, bilinçli ve duyarlı olduğu, \%15,7'sinin ise farkında, bilinçli ve duyarlı olmadığı görülmüştür.

'Eğitim gördüğünüz yükseköğretim kuruluşunun çevre sorunlarına karşı yeterli hassasiyet gösterdiğine inanıyor musunuz?' sorusuna katılanların \%20,5'inin 'Evet', \%79,5'inin 'Hayır' cevabını vermiştir.

Bu çalışmada 'üniversite öğrencilerinin lisans programında almış oldukları çevre eğitimi içerikli derslerin öğrencilerin çevre ile ilgili konularda farkındalık, bilinç ve duyarlııık seviyelerine katkı sağladığı yönünde' varsayımından yola çıkıldığı için öğrencilerin üniversitede almış oldukları çevre içerikli dersler ile çevre ile ilgili konularda farkındalık, bilinç ve duyarlılık seviyeleri arasında ilişki olup olmadığı Ki-kare testine göre karşılaştırılmıştır. Pearson Ki-kare değeri $(p .=0,000) 0,05$ 'ten küçük olduğu için öğrencilerin üniversitede almış oldukları çevre içerikli derslerin öğrencilerin çevre ile ilgili konularda farkındalık, bilinç ve duyarlılık seviyelerine katkı sağladığı sonucu elde edilmiştir. Benzer şekilde; öğrencilerin okudukları sınıfın da $(p=0,005)$ çevre ile ilgili konularda farkındalık, bilinç ve duyarlııı seviyelerine etki ettiği görülmüştür (Tablo 5).

Tablo 5. Öğrencilerin okudukları sınıf ile çevre ile ilgili konularda farkındalık, bilinç ve duyarlılık seviyeleri arasındaki ilişkiyi gösteren Pearson Ki-kare değeri

\begin{tabular}{|l|c|c|c|}
\hline & Value & df & Asymp. Sig. (2-sided) \\
\hline Pearson Chi-Square & $12,966^{*}$ & 3 &, 005 \\
\hline Likelihood Ratio & 14,444 & 3 &, 002 \\
\hline $\begin{array}{l}\text { Linear-by-Linear Associa- } \\
\text { tion }\end{array}$ & 7,892 & 1 &, 005 \\
\hline N of Valid Cases & 112 & & \\
\hline
\end{tabular}

${ }^{*} 0$ cells $(, 0 \%)$ have expected count less than 5 . The minimum expected count is 5,46 .

Öğrencilerin okudukları sınıf ile çevre kavramını doğru bir şekilde tanımlayıp tanımlayamadığı arasında anlamlı bir ilişki bulunmamaktadır $(p=0,077)$, yani öğrencilerin okudukları sınıf ile çevre kavramını doğru bir şekilde tanımlamaları birbirinden bağımsızdır (Tablo 6). Öğrencilerin okudukları sınıf ile sürdürülebilirlik kelimesini daha önce duyup duymadığı arasında anlamlı bir iliş̧i bulunmaktadır $(p=0,000)$ (Tablo 7). Birinci sınıf öğrencilerinin $\% 65$ 'i sürdürülebilirlik kelimesini daha önce duymadığını ilk defa üniversitede duyduğunu, ikinci sınıf, üçüncü sınıf ve dördüncü sınıf öğrencilerinin ise üniversitede lisans programında aldıkları çevre eğitimi içerikli derslerde duyduğunu belirtmiştir.

Tablo 6. Öğrencilerin okudukları sınıf ile çevre kavramını tanımlama arasındaki ilişkiyi gösteren Pearson Ki-kare değeri

\begin{tabular}{|l|c|c|c|}
\hline & Value & df & Asymp. Sig. (2-sided) \\
\hline Pearson Chi-Square & $11,392^{\star}$ & 6 &, 077 \\
\hline Likelihood Ratio & 10,807 & 6 &, 095 \\
\hline $\begin{array}{l}\text { Linear-by-Linear Associa- } \\
\text { tion }\end{array}$ & 2,706 & 1 &, 100 \\
\hline N of Valid Cases & 112 & & \\
\hline
\end{tabular}

${ }^{*} 7$ cells $(58,3 \%)$ have expected count less than 5 . The minimum expected count is 1,37 .

Tablo 7. Öğrencilerin okudukları sınıf ile sürdürülebilirlik kelimesini duyma arasındaki ilişkiyi gösteren Pearson Kikare değeri

\begin{tabular}{|l|c|c|c|}
\hline & Value & df & Asymp. Sig. (2-sided) \\
\hline Pearson Chi-Square & $30,031^{*}$ & 3 &, 000 \\
\hline Likelihood Ratio Associa- & 25,416 & 3 &, 000 \\
\hline $\begin{array}{l}\text { Linear-by-Linear An } \\
\text { tion }\end{array}$ & 20,969 & 1 &, 000 \\
\hline N of Valid Cases & 112 & & \\
\hline
\end{tabular}

$* 3$ cells $(37,5 \%)$ have expected count less than 5 . The minimum expected count is 3,49 
Öğrencilerin okudukları sınıf haricinde demografik ve sosyo-ekonomik özelliklerine bağlı olmaksızın çevre sorunlarının farkında olduğu, çevre konusunda bilinçli olduğu ve çevreye duyarlı olduğu görülmektedir. Öğrenciler, bu durumun üniversitede lisans programında almış oldukları çevre eğitimi içerikli derslerle ilgili olduğunu ancak ülkemizde çevre sorunlarına karşı yeterli hassasiyetin gösterilmediğini belirtmişlerdir.

\section{SONUÇLAR}

Sanayi Devriminden sonra insanın doğaya bakış açısı değişmiş ve doğaya egemen olmaya çalışmıştır. İnsanoğlu doğal kaynakları hiç tükenmeyecekmiş gibi bilinçsizce kullanarak kentlerdeki yeşil alanları tahrip ederek betonlaşan ve gri tonlarına hâkim kentlere dönüştürmüştür. Bu durum; kentlerdeki yeşil alanlarda görülen parçalanma ve bağlantı kopukluğunun kent iklimi ve kent ekosistemi açsından önemli problemler oluşturmasına, çevre sorunlarının artmasına ve insan sağlığını tehdit edecek ciddi boyutlara ulaşmasına neden olmuştur. Çevre bilinci ve sürdürülebilirlik ilkesi yok sayılarak kurulan kentler, dünyanın ekolojik dengesini olumsuz etkilemektedir. Çevre sorunlarının çözümünde insanların çevre bilincine sahip olması ve çevre eğitimi alması önemlidir. Çevre eğitimi, okul öncesi eğitimden başlayarak yükseköğretime kadar öğrencileri çevre sorunları hakkında eğitmenin bir yolu olarak görülmektedir. İnsanların çevreye bakış açılarını değiştirmeleri için üniversite öğrencilerine büyük sorumluluk düşmektedir, bu yüzden üniversite öğrencilerinin daha güvenli bir gelecek sağlamak adına çevre eğitimi alıp bilinçlenmeleri gerekmektedir.

Bu çalışmada, doğal ve kültürel kaynakları koruma-kullanma dengesi içerisinde tasarlanmasını, planlanmasını ve yönetilmesini ele alan, insan ile çevre arasındaki ilişkiyi irdeleyen, sanatı, bilimi, mühendisliği ve teknolojiyi birleştiren bir meslek disiplini olan peyzaj mimarlığı lisans öğrencilerinin üniversitede almış oldukları çevre eğitimi içerikli derslerin öğrencilerin çevre ile ilgili konularda farkındalık, bilinç ve duyarlılık seviyelerine katkı sağlayıp sağlamadığı ortaya konulmuştur. Bu doğrultuda Çabuk ve Karacaoğlu (2003), Özdemir ve ark. (2004), Oğuz ve ark. (2010, 2011), Erdal ve ark. (2013), Demirtaş ve ark. (2018), Gül ve ark. (2018)'nın yapmış olduğu çalışmalar incelenerek, üniversitede lisans programında verilen çevre eğitimi içerikli derslerin öğrencilerin çevre ile ilgili konularda farkındalık, bilinç ve duyarılıı seviyelerine katkı sağlayıp sağlamadığını belirlemek amacıyla bir anket çalışması yapılmıştır.

Çalışmada elde edilen bulgular; öğrencilerin üniversitede almış oldukları çevre içerikli dersler, öğrencilerin okudukları sınıf ile çevreye karşı olan farkındalık, bilinç ve duyarlılık seviyeleri arasında istatistiksel olarak anlamlı bir ilişki olduğunu göstermektedir. Benzer bir sonuç, Çabuk ve Karacaoğlu (2003)'nun, Kılıç ve İnal (2010)'ın, Yaylı ve Berk (2010)'in, Gürbüz ve Çakmak (2012)'ın, Erdal ve ark. (2013) 'nın, Gül ve ark.'nın (2018) yaptığı çalışmalarda da görülmüştür. Öğrencilerin ilköğretim ve ortaöğretimde çevre ile ilgili temel bilgilere sahip oldukları varsayıldığı için çalışmada bilgi seviyelerini tespit etmeye yönelik sorular sorulmamıştır. Ancak, birinci sınıf öğrencilerinin ikinci sınıf, üçüncü sınıf ve dördüncü sınıf öğrencilerine göre çevre kavramını tam ve doğru olarak ifade edemedikleri belirlenmiştir. Oğuz ve ark. (2011)'nın yapmış olduğu çalışmada da birinci ve dördüncü sınıf öğrencilerinin çevre kavramını tam olarak tanımlayamadıkları görülmüştür. Benzer şekilde; birinci sınıf öğrencilerinin sürdürülebilirlik kelimesini daha önce duymadığı ilk defa üniversitede duyduğu, ikinci sınıf, üçüncü sınıf ve dördüncü sınıf öğrencilerinin ise üniversitede lisans programında aldıkları çevre eğitimi içerikli derslerde sürdürülebilirlik kelimesini duyduğu belirlenmiştir. Bu bulgular çerçevesinde üniversitede çevre ile ilgili verilen derslerin sayısının özellikle birinci yarıyıldan itibaren arttırılması gerektiği söylenebilir. Öğrencilerin çoğunun Türkiye'de görülen çevre sorunlarının farkında ve bilincinde olduğu, Türkiye'de çevre konusunda faaliyet gösteren başlıca STK'ları tanımasına rağmen katılımcı olarak bu organizasyonlara ilgi göstermedikleri de belirlenmiştir. Wong (2003)'un, Talay ark. (2004)'nın, Oğuz ark. (2010, 2011)'nın, Erdal ark. (2013)'nın, Özen ve Özen (2017)'in yapmış olduğu çalışmalarda da üniversite öğrencilerinin çevre sorunlarının farkında ve bilincinde olduğu, çalışma sonuçlarının benzerlik gösterdiği görülmüştür.

Sonuç olarak; Amasya Üniversitesi Mimarlık Fakültesi Kentsel Tasarım ve Peyzaj Mimarlığı Bölümü'nde çevre eğitimi içerikli ders alan öğrencilerin çevre ile ilgili konularda farkındalık sahibi olduğu, bilinç ve duyarlılık seviyelerinin yüksek olduğu görülmüştür. Öğrencilerin çevre ile ilgili konularda farkındalık, bilinç ve duyarlılık seviyeleri ile tutum ve davranışlarının doğru orantılı olduğu saptanmıştır. Peyzaj mimarlığı insan ile çevre arasındaki ilişkiyi irdeleyen bir meslek disiplini olduğu için öğrencilerin çevre sorunlarının farkında olması, çevre ile ilgili konularda bilinç ve duyarlılık seviyesinin yüksek olması beklenen bir durumdu. Eğitim ömür boyu devam eden bir süreç olduğundan dolayı çevre eğitimi içerikli derslerin sadece üniversitede lisans programı içerisinde değil erken çocukluk döneminden itibaren verilmesi ve çevreye yönelik ders sayısının arttırılması gerekmektedir. Çevre sorunlarının mücadelesinde çevre ile ilgili konularda farkındalık sahibi, bilinç ve duyarlılık seviyesi yüksek gençlere büyük sorumluluk düşmektedir. Bu yüzden üniversite öğrencilerinin lisans programında çevre eğitimi alıp bilinçlenmeleri daha güvenli ve sürdürülebilir bir gelecek sağlamak adına önemlidir. 
Üniversite Öğrencilerinin Çevre Konularında Farkındalık, Bilinç ve Duyarlılık Seviyesinin Belirlenmesine Yönelik Bir Çalışma: Amasya Üniversitesi Kentsel Tasarım ve Peyzaj Mimarlığı Bölümü Örneği

\section{KAYNAKLAR}

Aminrad, Z., Zakaria, S. Z. B. S., Hadi, A. S. (2011). Influence of Age and Level of Education on Environmental Awareness and Attitude: Case Study on Iranian Students in Malaysian Universities. The Social Sciences, 6 (1): 15-19.

Aydın, F. (2011). Üniversite Öğrencilerinin 'Çevre' Kavramına İlişkin Metaforik Algıları. Doğu Coğrafya Dergisi 16 (26): 25-44.

Başal, H., A. (2003). Okulöncesi Eğitimde Uygulamalı Çevre Eğitimi. In: Erken Çocuklukta Gelişim ve Eğitimde Yeni Yaklaşımlar. Sevinç M. (eds.), Morpa Kültür Yayınları, İstanbul, 366-378.

Bozkurt, O., Cansüngü, K. Ö. (2002). İlköğretim Öğrencilerinin Çevre Eğitiminde Sera Etkisi İle İlgili Kavram Yanılgıları. Hacettepe Üniversitesi Eğitim Fakültesi Dergisi 23: 61-72.

Çabuk, B., Karacaoğlu, Ö. C. (2003). Üniversite Öğrencilerinin Çevre Duyarlılıklarının İncelenmesi. Ankara Üniversitesi Ĕgitim Bilimleri Fakültesi Dergisi 36 (1-2): 189-198.

Çevre Kanunu (2020). Resmi Gazete (Sayı: 18132) (Web sayfası: $\quad$ https://www.mevzuat.gov.tr/MevzuatMetin/1.5.2872.pdf) (Erişim tarihi: 29.01.2020).

Çifci, S., Şakacı, B. K. (2015). Çevre Bilinçli Tüketicilerin Firmaları Ödüllendirme ve Cezalandırma İsteklilikleri: Kadın ve Erkek Tüketiciler Arasındaki Farklılıklar. Eskişehir Osmangazi Üniversitesi IiBF Dergisi 10 (1): 287-296.

Çolakoğlu, E. (2010). Haklar Söyleminde Çevre Eğitiminin Yeri ve Türkiye'de Çevre Eğitiminin Anayasal Dayanakları. TBB Dergisi, 88: 151-171.

Demir, C., Çevirgen, A. (2006). Ekoturizm Yönetimi. Nobel Akademik Yayıncılık, Ankara.

Demirkaya, H. (2006). Çevre Eğitiminin Türkiye'deki Coğrafya Programları İçerisindeki Yeri ve Çevre Eğitimine Yönelik Yeni Yaklaşımlar. Fırat Üniversitesi Sosyal Bilimler Dergisi 16 (1): 207-222.

Demirtaş, N., Akbulut, M. C., Özşen, Z. S. (2018). Üniversite Öğrencilerinin Çevre Okuryazarlığı Üzerine Bir Araştırma: Beypazarı Meslek Yüksekokulu Örneği. Anadolu Çevre ve Hayvancılık Bilimleri Dergisi 3 (1): 27-33.

Deniş, H., Genç, H. (2010). İlköğretim Sekizinci Sınıf Öğrencilerinin Yaşadıkları Çevrede Bulunan Milli Parklara Yönelik Tutumlarının Bazı Değişkenlere Göre İncelenmesi (Isparta İli Örneği). Mehmet Akif Ersoy Üniversitesi Fen Bilimleri Enstitüsü Dergisi, 1: 9-25.

Erdal, H., Erdal, G., Yücel, M. (2013). Üniversite Öğrencilerinin Çevre Bilinç Düzeyi Araştırması: Gaziosmanpaşa Üniversitesi Örneği. Gaziosmanpaşa Bilimsel Araştırma Dergisi, 4: 57-65.

Ertürk, H. (1996). Çevre Bilimlerine Giriş. Uludağ Üniversitesi Güçlendirme Vakfı Yayınları, Bursa.

Ertürk, H. (2018). Çevre Bilimleri. Ekin Basım Yayın Dağıtım, Bursa.

Gül, S., Aydoğmuş, M., Çobanoğlu, İ. H., Türk, H. (2018). Üniversite Öğrencilerinin Çevre Bilinçlerinin İncelenmesi: Ondokuz Mayıs Üniversitesi Örneği. Gazi Eğitim Bilimleri Dergisi, 4 (3): 13-28.

Gürbüz, H., Çakmak, M. (2012). Biyoloji Eğitimi Bölümü Öğrencilerinin Çevreye Yönelik Tutumlarının İncelenmesi. Dicle Üniversitesi Ziya Gökalp Eğitim Fakültesi Dergisi, 19: 162-173.
Karataş, A. (2014). Çevre Sorunlarına Yönelik Bir Çözüm Aracı Olarak Yükseköğretimde Çevre Eğitimi. 2. Uluslararası Ahlak ve Çevre Sempozyumu, 24-26 Kasım, 2014, Adıyaman, Türkiye, Sempozyum Kitabı, 418-425.

Keleş, R., Hamamcı, C., Çoban, A. (2015). Çevre Politikası. İmge Kitapevi, Ankara.

Kılıç, S., İnal, M. E. (2010). Yüksek Öğretimde Çevre Eğitimi Alan ve Almayan Öğrencilerde Çevre Bilinci: Niğde Üniversitesi Örneği. Niğde Üniversitesi IïBF Dergisi, 3 (2): 70-83.

Kızılaslan, H., Kızılaslan, N. (2005). Çevre Konularında Kırsal Halkın Bilinç Düzeyi ve Davranışları (Tokat İli Artova İlçesi Örneği). Uluslararası Yönetim İktisat ve İşletme Dergisi 1 (1): 67-88.

Leiss, W. (1970). Utopia and Technology: Reflections on the Conquest of Natura. International Social Science Journal, 22 (4): 576-588.

Maffia, A. M. C., Silva, E., Jacovine, L. A. G. (2011). Environment and environmental awareness: how university students conceive and act. Acta Scientiarum: Biological Sciences, 33 (2): 209-214.

McKeown-Ice, R. (2000). Environmental Education in the United States: A Survey of Preservice Teacher Education Programs. The Journal of Environmental Education, 32 (1): 4-11.

Morgil, İ., Arda, S., Seçken, N., Yavuz, S., Özyalçın Oskay, Ö. (2004). The Influence of Computer-Assisted Education on Environmental Knowledge and Environmental Awareness. Chemistry Education Research and Practice, 2 (5): 99-110.

Nazlıoğlu, M. D. (1991). Sürdürülebilir Kalkınma Açısından Kadın ve Çevre, Sürdürülebilir Kalkınma El Kitabı. Türkiye Çevre Sorunları Vakfı Yayını, Ankara.

Oğuz, D., Çakçı, I., Kavas, S. (2010). Environmental awareness of university students in Ankara, Turkey. Journal of Agricultural Research, 5 (19): 2629-2636.

Oğuz, D., Çakçı, I., Kavas, S. (2011). Yüksek Öğretimde Öğrencilerin Çevre Bilinci. Süleyman Demirel Üniversitesi Orman Fakültesi Dergisi 12: 34-39.

Onur, A. Çağlar, A., Salman, M. (2016). Pazarlamanın Sürdürülebilir Gelişmedeki Rolü. International Conference on Eurasian Economies, October 11-13, 2012, Almaty, Kazakhstan, Kongre Kitabı, 389-396.

Özdemir, O., Yıldız, A., Ocaktan, E., Sarışen, Ö. (2004). Tıp Fakültesi Öğrencilerinin Çevre Sorunları Konusundaki Farkındalık ve Duyarlılıkları. Ankara Üniversitesi Tıp Fakültesi Mecmuası, 57 (3): 117-127.

Özden, M. (2008). Environmental Awareness and Attitudes of Student Teachers: An Empirical Research. International Research in Geographical and Environmental Education, 17 (1): 40-55.

Özen, R., Özen, A. (2017). Fırat Üniversitesi Veteriner Fakültesi Öğrencilerinin Çevre Sorunları Konusunda Görüşleri Üzerine Bir Çalışma. Kocatepe Veterinary Journal, 10 (4): 247-255.

Özil, E., Uğursal, V. İ., Akbulut, U., Özpınar, A. (2008). Renewable Energy and Environmenatl Awareness and Opinions: A survey of University Students in Canada, Romania, and Turkey. International Journal of Green Energy, 5 (3): 174-188.

Öztek, Z. (2006). İlk ve Ortaöğretimde Çevre Eğitimi. II. Çevre Hekimliği Kongresi, 18-21 Ocak, Ankara, Türkiye, Kongre Kitabı, 210-212.

Panth, M. K., Verma, P., Gupta, M. (2015). The Role of Attitude in Environmental Awareness of Under Graduate Students. 
International Journal of Research in Humanities and Social Studies 2 (17): 55-62.

Ramirez, M. (2006). Sustainability in the education of industrial designers: the case for Australia. International Journal of Sustainability in Higher Education, 7 (2): 189-202.

Segalàs, J., Ferrer-Balas, D., Svanström, M., Lundqvist, U., Mulder, K. F. (2009). What has to be learnt for sustainability? A comparison of bachelor engineering education competences at three European universities. Sustainability Science, 4 (1): 17.

Şafak, G., Erkal, S. (1999). Çevre Eğitimi ve Aile. Eğitim ve Bilim, 23 (112): 63-66.

Talay, İ., Gündüz, S., Akpınar, N. (2004). On the Status of Environmental Education and Awareness of Undergraduate
Students at Ankara University, Turkey. International Journal of Environment and Pollution, 21 (3): 293-308.

UNDP (1993). United Nations Development Program. Human Development Report. New York: United Nations Development Program.

Wong, K. (2003). The Environmental Awareness of University Students in Beijing, China. Journal of Contemporary China, 12 (36): 519-536.

Yaylı, H., Berk, Z. (2010). Kentsel Çevre Sorunlarına Karşı Bir Çözüm Önerisi: Akıllı Binalar. Kent ve Toplum, 1: 97-107.

Young, G., L. (2011). Environmental Encyclopedia. Cengage Learning, Gale, China. 